\title{
Seasonal and interannual variation of bacterial production in lowland rivers of the Orinoco basin
}

\author{
MARÍA M. CASTILLO,$*$ J. DAVID ALLAN, ${ }^{*}$ ROBERT L. SINSABAUGH ${ }^{\dagger}$ AND GEORGE W. KLING \\ *School of Natural Resources and Environment, The University of Michigan, Ann Arbor, MI, U.S.A. \\ ${ }^{+}$Department of Biology, University of New Mexico, NM, U.S.A. \\ ${ }^{\ddagger}$ Department of Ecology and Evolutionary Biology, University of Michigan, Ann Arbor, MI, U.S.A.
}

\section{SUMMARY}

1. We examined the influence of hydrologic seasonality on temporal variation of planktonic bacterial production (BP) in relatively undisturbed lowland rivers of the middle Orinoco basin, Venezuela. We sampled two clearwater and two blackwater rivers over 2 years for dissolved organic carbon (DOC), chlorophyll, phosphorus and bacterial abundance to determine their relationship to temporal variation in BP.

2. Dissolved organic carbon concentration was greater in blackwater (543-664 $\mu \mathrm{M})$ than in clearwater rivers (184-240 $\mu \mathrm{M})$, and was generally higher during periods of rising and high water compared with low water. Chlorophyll concentration peaked $\left(3 \mu \mathrm{g} \mathrm{L}^{-1}\right)$ during the first year of study when discharge was lowest, particularly in blackwater rivers. Soluble reactive phosphorus (SRP) was very low in the study rivers $\left(<3.8 \mu \mathrm{g} \mathrm{L}^{-1}\right)$ and concentration increased during low water.

3. Average BP was higher in clearwater $\left(0.20-0.26 \mu \mathrm{g} \mathrm{C} \mathrm{L}^{-1} \mathrm{~h}^{-1}\right)$ than in blackwater rivers (0.14-0.17 $\left.\mu \mathrm{g} \mathrm{C} \mathrm{L}^{-1} \mathrm{~h}^{-1}\right)$, although mean bacterial abundance was similar among rivers $\left(0.6-0.8 \times 10^{6}\right.$ cells $\left.\mathrm{mL}^{-1}\right)$.

4. Periods of higher chlorophyll $a$ concentration (low water) or flushing of terrestrial organic material (rising water) were accompanied by higher BP, while low BP was observed during the period of high water.

5. Interannual variation in BP was influenced by variations in discharge related to El Niño Southern Oscillation events.

6. Seasonal variation in BP in the study rivers and other tropical systems was relatively small compared with seasonal variation in temperate rivers and lakes. In addition to the low seasonal variation of temperature in the tropics, low overall human disturbance could result in less variation in the inputs of nutrients and carbon to the study rivers compared with more disturbed temperate systems.

Keywords: bacterial production, El Niño Southern Oscillation, Orinoco, tropical rivers, Venezuela

\section{Introduction}

Planktonic heterotrophic bacteria are important in aquatic ecosystems as mineralisers of organic matter and as components of the food web. Planktonic

Correspondence: María M. Castillo, Departamento de Estudios Ambientales, Universidad Simón Bolívar, Apartado 89000,

Caracas 1080-A, Venezuela.

E-mail: muzcanga@usb.ve bacteria are responsible for much of the respiration in large rivers, and they may affect the amount and quality of carbon transported by large rivers to the oceans (Richey et al., 1990; Findlay et al., 1992; Benner et al., 1995). Planktonic bacteria also represent a source of carbon to higher trophic levels because bacterivores graze on bacteria and in turn may be consumed by protozoans, crustaceans and insects (Meyer, 1994; Wetzel, 1995). Thus, the magnitude and pattern of temporal variation in bacterial activity will 
affect the influence of planktonic heterotrophic bacteria on the biogeochemistry of carbon and nutrients. Although temperature, organic carbon and nutrient availability are generally known for their influence on bacterial activity (Kirchman, 1990; Morris \& Lewis, 1992; Ochs, Cole \& Likens, 1995), our understanding of the specific environmental mechanisms that determine the influence of these factors on bacterial production (BP) in any particular setting is limited.

In temperate systems, temporal changes in planktonic $\mathrm{BP}$ are primarily related to seasonal variation in temperature and the availability of substrate and inorganic nutrients. BP is strongly influenced by temperature in temperate systems, exhibiting marked differences between cooler and warmer months (Edwards \& Meyer, 1986; Servais, 1989; Findlay et al., 1991; Coveney \& Wetzel, 1995). In some temperate lakes, temperature and BP are positively correlated below certain critical levels $\left(10^{\circ} \mathrm{C}\right.$, Lake Michigan, Scavia \& Laird, 1987; $14{ }^{\circ} \mathrm{C}$, Mirror Lake, NH, Ochs et al., 1995). Above these thresholds BP can be limited both by nutrient concentrations (Morris \& Lewis, 1992; Castillo, Kling \& Allan, 2003) and substrate quality (Kirchman, 1990; Pace \& Cole, 1994; Felip, Pace \& Cole, 1996). In some temperate rivers, BP is increased by inputs of labile substrate from primary producers during warmer months (Servais, 1989; Admiraal et al., 1994; Berger et al., 1995; Sinsabaugh et al., 1997). Discharge also can affect planktonic BP in temperate rivers by influencing the source and activity of bacteria during periods of low and high water (Edwards \& Meyer, 1986). Thus, seasonality appears to have a strong influence on factors controlling BP.

In contrast to temperate systems, tropical lowland rivers have continuously high temperatures; consequently, substrate and inorganic nutrient availability are likely to be important in controlling bacterial metabolism. In the main stem of the Amazon, experimental evidence suggests that BP is limited by carbon while in the Río Negro, a blackwater tributary, carbon, nitrogen and phosphorus colimit BP (Benner et al., 1995). In clearwater and blackwater rivers of the Orinoco basin, phosphorus limits BP at most times, while carbon is a secondary limiting element (Castillo et al., 2003). In these ecosystems rainfall and discharge are highly seasonal, which affects the concentration of suspended and dissolved substances, the density of planktonic organisms (Lewis, Saunders \& Dufford, 1990), and the amount of BP (Healey, Moll \& Diallo,
1988; Benner et al., 1995). This hydrological seasonality could influence the availability of nutrients and carbon to bacteria. In the Gambia River, bacteria took up glucose faster during low and rising water, when chlorophyll $a$ concentration was greater than during high water, indicating the importance of high-quality substrate (Healey et al., 1988). In the Amazon system, $\mathrm{BP}$ increased during high water, probably because of inputs of labile carbon from 'varzea' grasses, suggesting that the presence of floodplain lakes could also influence the delivery of labile carbon to the river main stem (Benner et al., 1995). Although bacteria showed temporal changes related to substrate availability in these two tropical systems, the sources of DOC (algal versus macrophyte) and the patterns of variation in $\mathrm{BP}$ were different, suggesting that the causes of variation in BP could differ among systems.

Our study examines seasonal variation in planktonic BP and its relationship with potential controlling factors, such as organic carbon and nutrient concentrations, in lowland rivers of the middle Orinoco basin. Because these rivers have little human influence, we expect that variation in the environmental factors that control BP will be due to temporal and spatial changes in natural attributes of the rivers and their catchments. Specifically, we hypothesise that seasonal changes in carbon and nutrient availability that drive BP are tied to hydrologic seasonality. We investigate this hypothesis by comparing temporal variation in BP between two blackwater and two clearwater rivers that differ in their water chemistry, floodplain connectivity, and surrounding vegetation. In addition, we compare the seasonal variation in bacterial abundance and production between systems that differ in their latitudinal location and discuss the potential mechanisms that may explain the observed patterns.

\section{Methods}

\section{Site description}

The Cataniapo, Cuao, Sipapo and Autana rivers are located south of the city of Puerto Ayacucho in the Middle Orinoco River basin, Amazonas State, Venezuela. The Cuao and the Autana Rivers flow into the Sipapo River, which is a tributary of the Orinoco. In Puerto Ayacucho, mean annual temperature is $26.7^{\circ} \mathrm{C}$ and mean annual precipitation $2300 \mathrm{~mm}$ (Ministerio 
del Ambiente y de los Recursos Naturales, weather station 6424, years of record 1953-96). Two seasons can be defined in terms of the distribution of precipitation throughout the year: a dry season from October to March and a rainy season from April to September.

The Cataniapo and the Cuao are clearwater rivers while the Sipapo and the Autana are blackwater rivers, according to the classification of Sioli (1984) for the rivers of the Brazilian Amazon region. Blackwater rivers are characterised by lower $\mathrm{pH}(<5)$ and a higher concentration of dissolved organic carbon (DOC) (4$8 \mathrm{mg} \mathrm{L}^{-1}$ ) than clearwater rivers. Both types of river have low conductivity $\left(<12.5 \mu \mathrm{Sm}^{-1}\right)$, which is characteristic of undisturbed rivers draining the highly weathered Guayana Shield (Weibezahn, 1990; Lewis, Hamilton \& Saunders, 1995; Castillo, 2000). Both types of river experience a similar topographic gradient from mountains in their headwaters to alluvial plains in the lower basin. However, the alluvial plains are much more extensive in the Autana and Sipapo than in the Cataniapo and Cuao, resulting in extensive floodplains in the blackwater rivers. The Autana and Sipapo floodplains are covered primarily by forest (Huber, 1995) that is flooded during the period of high water. In contrast, the clearwater rivers remain in their channels during the period of high water.

\section{Field sampling}

Sampling was conducted on 17 occasions from September 1997 to July 1999 in the lower section in all four rivers. Sampling dates were selected to include the periods of low, rising, high and falling water. The Cataniapo River was sampled upstream $\left(5^{\circ} 35^{\prime} 27^{\prime \prime} \mathrm{N}\right.$, $67^{\circ} 35^{\prime} 40^{\prime \prime} \mathrm{W}$ ) from the inflow of a highly disturbed lower basin tributary (Caño Carinagua). The Cuao and Autana rivers were sampled near their mouths (Cuao: $4^{\circ} 57^{\prime} 10^{\prime \prime} \mathrm{N}, 67^{\circ} 41^{\prime} 21^{\prime \prime} \mathrm{W}$; Autana: $4^{\circ} 44^{\prime} 52^{\prime \prime} \mathrm{N}$, $67^{\circ} 41^{\prime} 37^{\prime \prime} \mathrm{W}$ ) approximately $1 \mathrm{~km}$ above their confluence with the Sipapo River, which in turn was sampled above its confluence $\left(4^{\circ} 42^{\prime} 42^{\prime \prime} \mathrm{N} ; 67^{\circ} 45^{\prime} 8^{\prime \prime} \mathrm{W}\right)$ with the Autana River. Channel width, depth, and current velocity were measured at six to seven points at each river cross section to estimate discharge. Water velocity was measured with a General Oceanics S2030-R current meter (General Oceanics Inc., Miami, FL, U.S.A.). Water sampling was conducted at the cross-sectional point where water velocity was highest. Air and water temperature and Secchi depth were measured at each site. Three depth-integrated water samples were collected at each site for estimation of DOC concentration, BP and abundance. For water chemistry analyses, the three samples were pooled.

\section{Chemical analyses}

Water samples were kept cold and dark until analysis, conducted on average within a week of sample collection and with a maximum delay of a month. $\mathrm{pH}$ was measured with an Orion 230A pH meter, and conductivity with an Orion 122 conductivity meter (Orion Research Inc., Beverly, MA, U.S.A.). The concentration of nitrate was analysed by the cadmium reduction method and ammonium by the phenate method (A.P.H.A., 1995). Soluble reactive phosphorus (SRP) was determined with the ascorbic acid method, and total phosphorus was analysed by digestion with persulphate followed by analysis for SRP (A.P.H.A., 1995). Chlorophyll a concentration was analysed spectrophotometrically using a hot ethanol extraction (Nusch, 1980). Samples for DOC analysis were filtered on site through precombusted $\left(450^{\circ} \mathrm{C}, 2 \mathrm{~h}\right) \mathrm{GF} / \mathrm{F}$ filters and adjusted to $\mathrm{pH} 2$ with $6 \mathrm{~N} \mathrm{HCl}$. Dissolved organic carbon samples were refrigerated and stored in the dark until analysis (within 2 months) using a platinum-catalysed combustion followed by infrared detection of $\mathrm{CO}_{2}$ (Shimadzu TOC-5000; Shimadzu, Columbia, MD, U.S.A.).

\section{Bacterial production and abundance}

Bacterial production was estimated by the rate of incorporation of tritiated leucine into protein (Simon \& Azam, 1989; Kirchman, 1993). One control and three subsamples of $10 \mathrm{~mL}$ each were taken from each depth-integrated water sample. Controls consisted of water samples with buffered (sodium acetate added, adjusted to $\mathrm{pH}$ 7) formalin (2\% final concentration) added prior to the addition of labelled leucine. Samples were incubated for $1 \mathrm{~h}$ in a cooler filled with river water and covered with plastic screen to maintain light and temperature conditions similar to the river. Incubations were ended by adding buffered formalin, and samples were stored in a cooler with ice until they were processed. Previous experiments have shown that buffered, formalin-killed samples can be 
stored for $36 \mathrm{~h}$ at $4{ }^{\circ} \mathrm{C}$ without significant changes in results (Castillo, 2000). Samples were processed within $30 \mathrm{~h}$ of collection. In the laboratory, proteins were extracted with 5\% trichloroacetic acid (TCA) for $15 \mathrm{~min}$ at $80^{\circ} \mathrm{C}$. Samples were allowed to cool and were filtered $(<150 \mathrm{~mm}$ of $\mathrm{Hg})$ through $0.22 \mu \mathrm{m}$ cellulose nitrate filters. Filters were rinsed twice with $3 \mathrm{~mL}$ of cold $5 \%$ TCA and twice with $2 \mathrm{~mL}$ of $80 \%$ ethanol. Filters were placed in scintillation vials and, when dry, dissolved by ethyl acetate $(1 \mathrm{~mL})$ overnight. Once dissolved, scintillation cocktail was added and the sample radio-assayed. A conversion factor of $3.1 \mu \mathrm{g}$ of carbon per nanomole of leucine was used to convert the leucine incorporation into carbon units (Kirchman, 1993).

During the periods of low (January 1999) and high water (July 1999), additional samples were collected in order to assess cross-sectional variation in BP. In addition to the main sampling point, two other sampling points, representing the lowest and intermediate water velocities, were selected. No statistical differences were found in $\mathrm{BP}$ across the river channel at all river sites during the periods of low and high water (Kruskal-Wallis $P>0.05$ ). These results suggest that samples from one point in the river can be considered representative of conditions across the channel.

Water samples for bacterial abundance were preserved with buffered formalin (Turley, 1993) and stored at $4{ }^{\circ} \mathrm{C}$ until analysis. Bacterial numbers were estimated from acridine orange epifluorescence counts on black polycarbonate Nucleopore $(0.22 \mu \mathrm{m})$ filters (Hobbie, Daley \& Jasper, 1977). Between 15 and 20 fields were observed in order to count at least 300 cells (Wetzel \& Likens, 1991). Bacterial doubling times were calculated from BP and bacterial abundance assuming $10 \mathrm{fg} \mathrm{C}$ cell $^{-1}$ (Bell, 1993) and that all bacterial cells were actively growing. Bacterial doubling times were compared with water residence times in the rivers, which were calculated by dividing the total river length (m) by the averaged cross channel water velocity $\left(\mathrm{m} \mathrm{s}^{-1}\right)$ and then converted to unit of days.

\section{Statistical analyses}

To test whether BP, bacterial abundance and DOC concentration showed seasonal variation, results were analysed using a two-way ANOVA (river by date). Separate analyses were conducted for each sampling year (first year: September 1997 to June 1998; second year: October 1998 to July 1999). The interaction between site and date was significant for the three dependent variables so treatment means (joint means) between clearwater and blackwater rivers were compared by multiple complex contrasts (Bonferroni) for each date. In addition, DOC, BP and bacterial abundance between high and low water were compared by complex contrasts (Bonferroni) for each river. The level of significance used was 0.05 . Levene's statistic and plots of residual against predicted values were used to test for homogeneity of variance, while normality was tested by cumulative probability plots and Kolmogorov-Smirnov assessment (Lilliefors correction) of the residuals. When departures from normality or homogeneity were observed, data were corrected in most cases by applying a logarithmic transformation. Spearman rank correlations $\left(r_{\mathrm{s}}\right)$ were calculated between microbiological (BP and abundance), water chemistry and hydrological (discharge, water residence time) variables because some departures from normality were uncorrectable.

\section{Results}

Physical and chemical variables

Water temperature ranged from 24 to $31{ }^{\circ} \mathrm{C}$ during the 2 years of study and was similar among study sites (Table 1). Higher temperatures were measured

Table 1 Mean and range of values of physical and chemical variables in the study rivers for the period September 1997 to July 1999

\begin{tabular}{lcccc}
\hline & Cataniapo & Cuao & Sipapo & Autana \\
\hline Water temperature $\left({ }^{\circ} \mathrm{C}\right)$ & $26.2(25-29)$ & $26.5(25-31)$ & $27.8(25-34)$ & $26.00(24-31)$ \\
Secchi disk depth $(\mathrm{m})$ & $1.71(1.2-2.5)$ & $1.74(1-2.6)$ & $1.96(1.6-2.6)$ & $2.04(1.3-2.5)$ \\
$\mathrm{pH}$ & $6.0(5.18-6.58)$ & $5.8(4.92-6.53)$ & $4.9(4.12-5.44)$ & $4.7(3.95-5.39)$ \\
Specific conductance $\left(\mu \mathrm{S} \mathrm{cm}^{-1}\right)$ & $6.3(4.9-9.4)$ & $6.3(4.8-9.5)$ & $6.9(4.81-0.8)$ & $9.1(5.8-12.5)$ \\
Nitrate $\left(\mu \mathrm{g} \mathrm{N}^{\left.-N_{3} \mathrm{~L}^{-1}\right)}\right.$ & $136.5(25.2-331.4)$ & $157.5(25.2-317.5)$ & $38.55(4.6-83.1)$ & $41.10(3.6-127.7)$ \\
SRP $\left(\mu \mathrm{g} \mathrm{L}^{-1}\right)$ & $1.0(0-3.8)$ & $1.2(0-3)$ & $1.1(0-3.5)$ & $1.0(0-3.0)$ \\
Total P $\left(\mu \mathrm{g} \mathrm{L}^{-1}\right)$ & $4.8(0.7-8.2)$ & $5.5(2.1-9.1)$ & $4.2(0-7.6)$ & $3.5(0-5.4)$ \\
\hline
\end{tabular}


during the period of low water (February to March) in both years. Water transparency was greater in the two blackwater rivers than in clearwater rivers.

Blackwater rivers had lower $\mathrm{pH}$ compared with the clearwater rivers and lower values were recorded during the periods of rising and high water (Table 1). Specific conductance was very low in all study rivers and lower in clearwater than in the blackwater rivers. The Cataniapo and Cuao had higher mean nitrate concentrations than did the Sipapo and Autana. Ammonium was below detection limits $\left(10 \mu \mathrm{g} \mathrm{L}^{-1}\right)$. SRP and total phosphorus concentrations were very low in all study rivers while mean total $\mathrm{P}$ concentration was slightly higher in clear than in blackwater rivers. SRP concentration was highest during the periods of low water (Fig. 1). During the 1998 dry season, total phosphorus concentration increased in the Cataniapo and the Sipapo rivers but showed no clear pattern during 1999.

\section{Discharge}

The Cuao River had the highest mean discharge $\left(291 \mathrm{~m}^{3} \mathrm{~s}^{-1}\right)$ while the Cataniapo had the lowest $\left(86 \mathrm{~m}^{3} \mathrm{~s}^{-1}\right.$ ) (Table 2). Discharge varied during the 2 years, the first being characterised by a greater difference in flow between the dry (February 1998) and the rainy season (June 1998), resulting in higher coefficients of variation in the first than in the second year (Table 2).

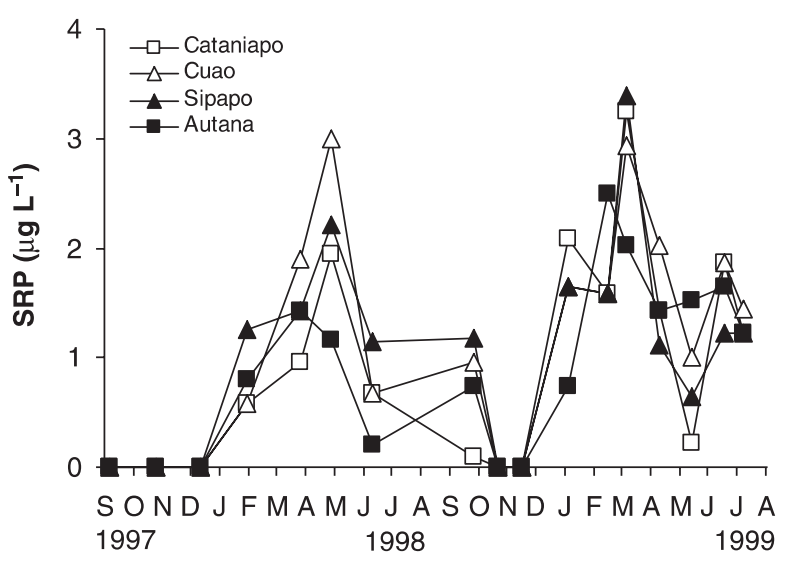

Fig. 1 Seasonal variation in SRP concentrations in the study rivers for the period September 1997 to July 1999.

\section{Dissolved organic carbon and chlorophyll}

Mean concentration of DOC was higher in blackwater (Sipapo, $543 \mu \mathrm{M}$; Autana, $664 \mu \mathrm{M}$ ) than in clearwater rivers (Cataniapo, $180 \mu \mathrm{M}$; Cuao, $240 \mu \mathrm{M}$ ) (Bonferroni, $P<0.0001$ ). Higher concentrations were observed during periods of high flow rather than low flow (Fig. 2) in both clearwater $\left(r_{\mathrm{s}}=0.624\right.$, $P<0.001, n=34)$ and blackwater $\left(r_{\mathrm{s}}=0.413\right.$, $P<0.001, n=34)$ rivers. During the first year, a higher concentration (Bonferroni, $P<0.006$ ) was observed during the high water (May to June) than during low water dates (February to April) in Cuao, Autana and Sipapo. During the second year, the

Table 2 Discharge $\left(\mathrm{m}^{3} \mathrm{~s}^{-1}\right)$, total P $\left(\mu \mathrm{g} \mathrm{L}{ }^{-1}\right)$, DOC $(\mu \mathrm{M})$, bacterial production $\left(\mu \mathrm{g} \mathrm{C} \mathrm{L} \mathrm{h}^{-1}\right)$ and bacterial abundance $\left(10^{6}\right.$ cells $\left.\mathrm{mL}^{-1}\right)$ in the study rivers. Values shown are mean \pm SD and coefficient of variation (\%) for the periods September 1997 to June 1998 and September 1998 to July 1999. Data for the Autana River for the period September 1997 to June 1998 were taken from Castillo (2000).

\begin{tabular}{|c|c|c|c|c|}
\hline & Cataniapo & Cuao & Sipapo & Autana \\
\hline \multicolumn{5}{|l|}{ Discharge } \\
\hline 1997-98 & $91 \pm 138(151)$ & $273 \pm 321(118)$ & $143 \pm 124(87)$ & $168 \pm 118(70)$ \\
\hline 1998-99 & $82 \pm 49(60)$ & $303 \pm 179(59)$ & $292 \pm 84(29)$ & $242 \pm 43(18)$ \\
\hline \multicolumn{5}{|l|}{ Total P } \\
\hline 1997-98 & $3.7 \pm 1.6(41.9)$ & $4.2 \pm 1.5(35.2)$ & $3.0 \pm 1.7(56.9)$ & $3.1 \pm 2.1(67.7)$ \\
\hline 1998-99 & $5.6 \pm 1.4(25.6)$ & $6.4 \pm 2.1(33.3)$ & $5.1 \pm 1.3(25.3)$ & $4.0 \pm 1.4(35.4)$ \\
\hline \multicolumn{5}{|l|}{ DOC } \\
\hline 1997-98 & $201.2 \pm 80.2(39.9)$ & $209.3 \pm 83.8(40.0)$ & $517.1 \pm 150.8(29.2)$ & $635.0 \pm 133.6(21.0)$ \\
\hline 1998-99 & $165.8 \pm 42.8(25.8)$ & $261.4 \pm 60.1(23.0)$ & $561.7 \pm 107.9(19.2)$ & $683.7 \pm 107.3(15.7)$ \\
\hline \multicolumn{5}{|c|}{ Bacterial Production } \\
\hline 1997-98 & $0.22 \pm 0.12(56.0)$ & $0.12 \pm 0.07(57.7)$ & $0.11 \pm 0.07(59.8)$ & $0.09 \pm 0.06(61.8)$ \\
\hline 1998-99 & $0.28 \pm 0.09(30.7)$ & $0.26 \pm 0.09(34.8)$ & $0.21 \pm 0.11(52.4)$ & $0.17 \pm 0.06(39.6)$ \\
\hline \multicolumn{5}{|c|}{ Bacterial abundance } \\
\hline 1997-98 & $0.75 \pm 0.13$ & $0.79 \pm 0.17(21.9)$ & $0.73 \pm 0.08$ & $0.84 \pm 0.15$ \\
\hline 1998-99 & $0.50 \pm 0.08$ & $0.57 \pm 0.13$ & $0.61 \pm 0.08$ & $0.63 \pm 0.07$ (11.4) \\
\hline
\end{tabular}



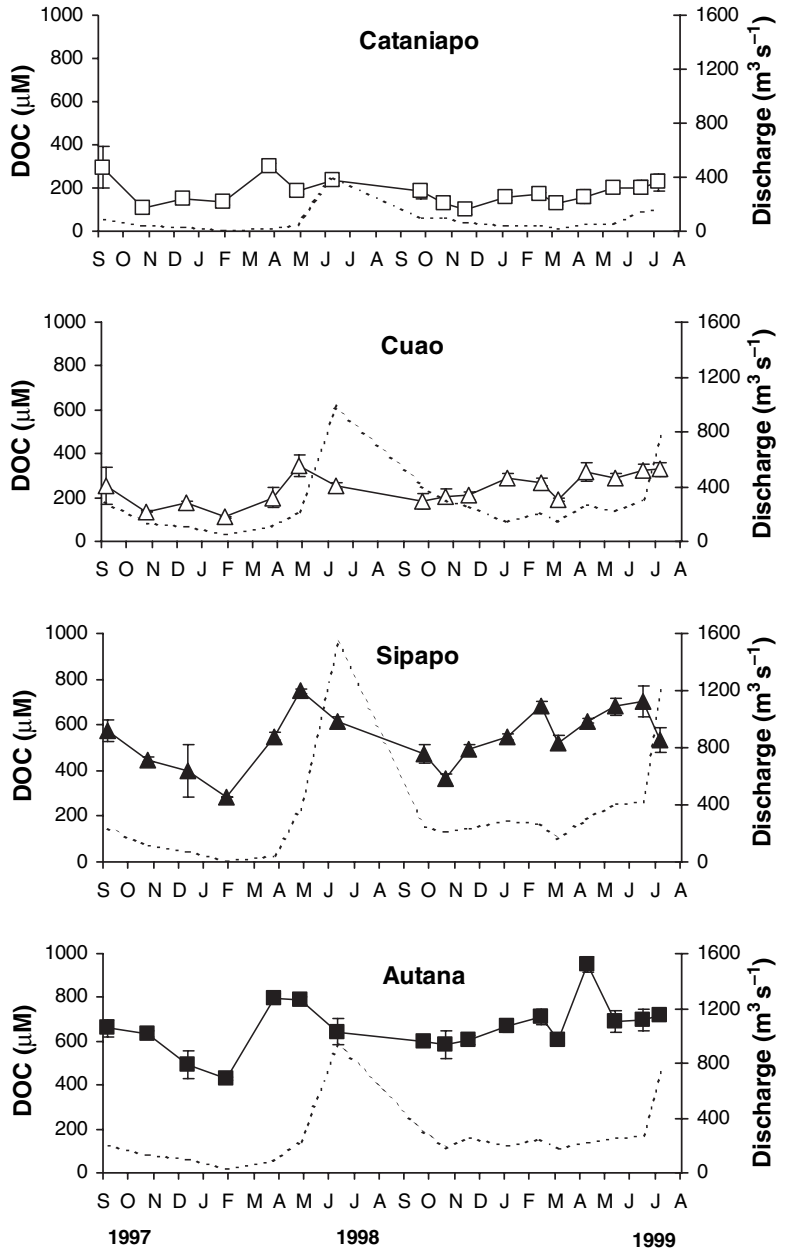

Fig. 2 Dissolved organic carbon (DOC) concentrations ( $\mu \mathrm{M})$ in the clearwater rivers (Cataniapo and Cuao) and blackwater rivers (Sipapo and Autana) for the period September 1997 to July 1999. Error bars represent one standard deviation. Discharge values $(Q)$ are shown as dotted lines. Data for the Autana River for the period September 1997 to June 1998 were taken from Castillo (2000).

temporal pattern in DOC concentration was less marked than in the first year, with a lower coefficient of variation (Table 2). In blackwater rivers, periods of high DOC concentration were accompanied by lower $\mathrm{pH}\left(r_{\mathrm{s}}=-0.432, P<0.011\right.$, $n=34)$.

Chlorophyll $a$ concentration was very low throughout the study period at all river sites $\left(<3 \mu \mathrm{g} \mathrm{L}^{-1}\right)$ (Fig. 3). During the 1998 dry season, when DOC concentration was lower, chlorophyll concentrations were higher, particularly in blackwater rivers. This trend in blackwater rivers is supported by a negative correlation between chlorophyll and discharge $\left(r_{\mathrm{s}}=\right.$

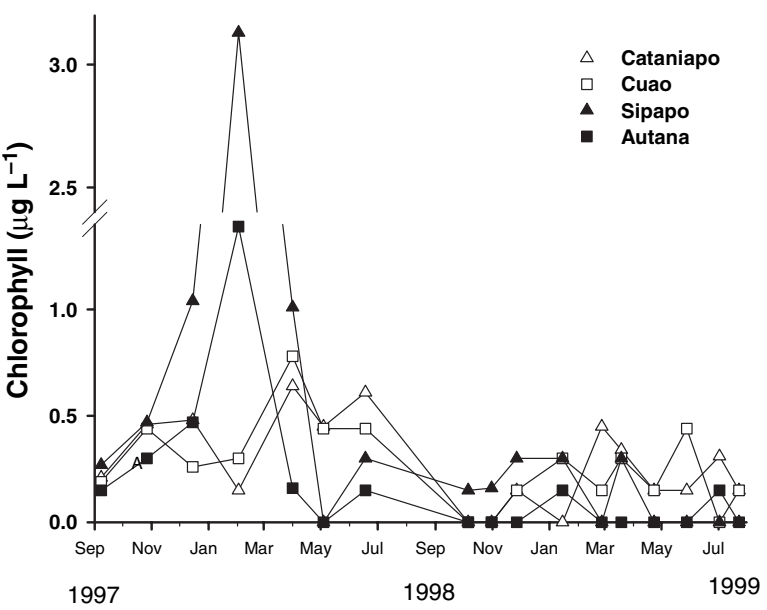

Fig. 3 Chlorophyll $a$ concentration in the study rivers for the period September 1997 to July 1999. Data for the Autana River for the period September 1997 to June 1998 were taken from Castillo (2000).

-0.622, $P<0.001, n=34)$ and between chlorophyll and DOC $\left(r_{\mathrm{s}}=-0.664, P<0.001, n=34\right)$.

\section{Bacterial production and abundance}

Bacterial production ranged between 0.03 and $0.54 \mu \mathrm{g} \mathrm{C} \mathrm{L} \mathrm{L}^{-1} \mathrm{~h}^{-1}$ in the study rivers. Blackwater rivers (Autana and Sipapo) had a lower mean BP than did clearwater rivers (Cuao and Cataniapo) (Table 2). Blackwater rivers exhibited lower BP than did clearwater rivers on more than half of the sampling dates (Bonferroni, $P<0.03$ ).

Bacterial production varied at all river sites during the 2 years of study (Bonferroni, $P<0.006$ ). It was low during high water and peaked during low, rising or falling water (Fig. 4). Increases in BP were accompanied by high $\mathrm{pH}$ (clearwater, $r_{\mathrm{s}}=0.580$, $P<0.01, n=34$; blackwater, $r_{\mathrm{s}}=0.660, P<0.01$, $n=34$ ) (Fig. 5a) and by low DOC concentrations, although a significant correlation was observed only during the second year in both types of rivers (blackwater, $r_{\mathrm{s}}=-0.571, P=0.006, n=20$; clearwater, $r_{\mathrm{s}}=-0.545, P=0.009, n=20$ ) (Fig. 5b). In blackwater rivers, $\mathrm{BP}$ and total phosphorus also showed a positive correlation $\left(r_{\mathrm{s}}=0.459, P=0.006\right.$, $n=34$ ) (Fig. 5c).

Mean BP values were lower during the first year of study. In contrast, seasonal variation was higher during the first year at all sites (Table 2). Higher variation in discharge and DOC during the first year of study was 
accompanied by higher variation (as percentage $\mathrm{CV}$ ) in $\mathrm{BP}$, particularly in the clearwater rivers.

Estimates of mean bacterial abundance showed less variation than $\mathrm{BP}\left(0.6-0.8 \times 10^{6}\right.$ cells $\left.\mathrm{mL}^{-1}\right)$ among the four study rivers during the 2-year sampling period (Fig. 6). Bacterial abundance was higher in blackwater than in clearwater rivers on over half of sampling dates (Bonferroni, $P<0.05$ ). Seasonal patterns were relatively similar among rivers during the first year, with lower numbers during low water. In contrast, bacterial abundance increased during periods of low flow at all river sites during the second year (Bonferroni, $P<0.005$ ).

Bacterial doubling time was longer during the first (1.3-3.6 days) than during the second year (0.51.1 days), and especially during the period of high water. Doubling time was negatively correlated with water residence times during the first year $\left(r_{\mathrm{s}}=\right.$ $-0.394, P=0.038, n=28$ ). Doubling time was shorter than water residence time on most sampling dates,
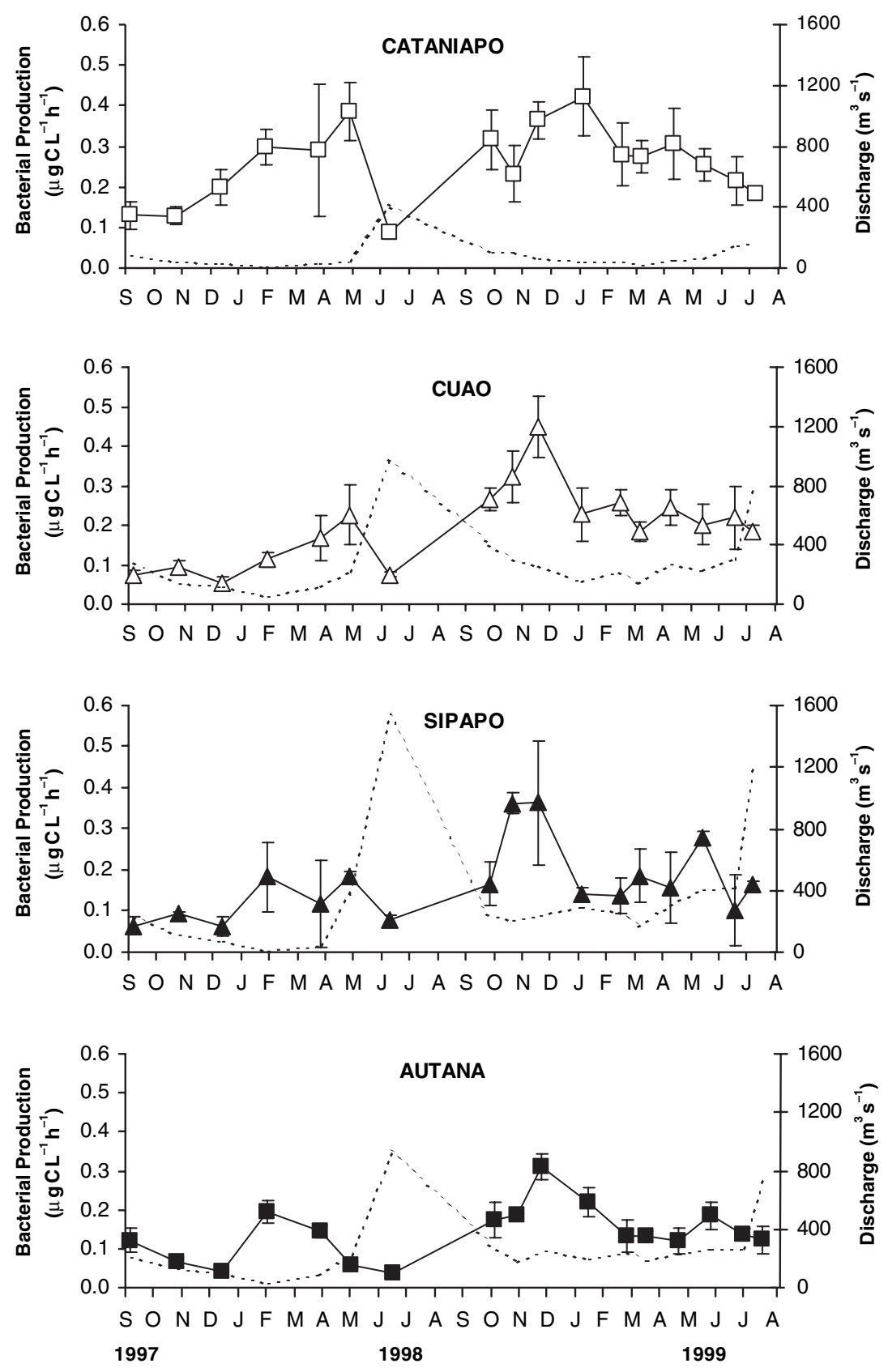

Fig. 4 Bacterial production in the clearwater (Cataniapo and Cuao) and blackwater rivers (Sipapo and Autana) for the period September 1997 to July 1999. Discharge values $(Q)$ are shown as dotted lines. Data for the Autana River for the period September 1997 to June 1998 were taken from Castillo (2000). 

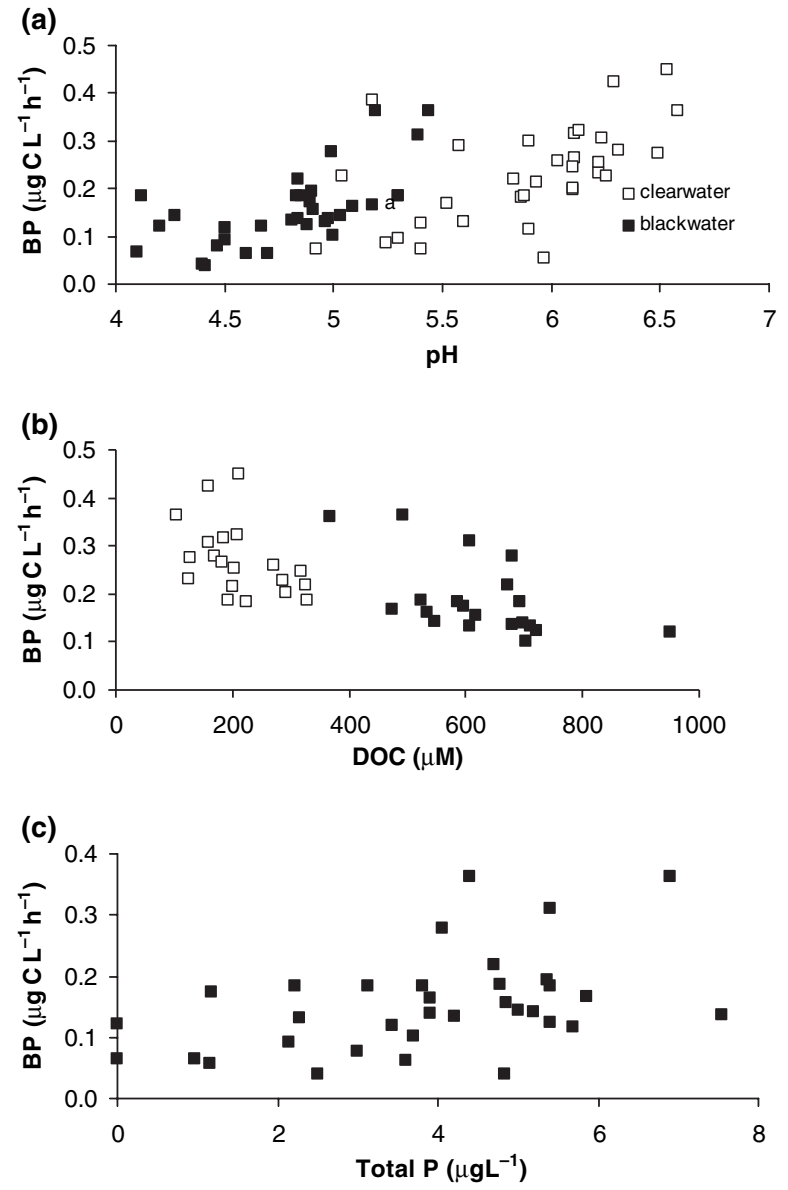

Fig. 5 Correlation between bacterial production and several variables. (a) $\mathrm{pH}$ (blackwater, $r_{\mathrm{s}}=0.660, P<0.01$; clearwater, $\left.r_{\mathrm{s}}=0.580, P<0.01\right)$. (b) DOC in blackwater $\left(r_{\mathrm{s}}=0.571, P=\right.$ $0.006)$ and clearwater $\left(r_{\mathrm{s}}=-0.545, P=0.009\right)$ for the second year; (c) Total phosphorous concentrations in blackwater rivers $\left(r_{\mathrm{s}}=0.459 ; P<0.006\right)$.

except in the blackwater Autana and in the clearwater rivers during high water (Fig. 7), because of high discharge and low BP during this period.

\section{Discussion}

\section{Seasonal changes in bacterial production}

Our results indicate that hydrologic seasonality drives fluctuations in BP in clearwater and blackwater rivers by changing resource availability and $\mathrm{pH}$. High $\mathrm{BP}$ at all river sites was observed primarily during periods of reduced flow when phosphorus, chlorophyll $a$ and $\mathrm{pH}$ increased. The present study supports similar findings reported previously for the Autana River (Castillo, 2000), and establishes that the influence of hydrologic seasonality is found in rivers of differing chemistry and varies across years of contrasting rainfall patterns. Based on bioassay experiments that showed bacterial response to $\mathrm{P}$ and carbon additions, including carbon from algal and terrestrial sources (Castillo et al., 2003), temporal variability of BP was expected to be related to variation in $\mathrm{P}$ concentration and inputs of labile organic carbon. Although BP increased during rising water, probably because of the flushing of fresh organic carbon from land, it was low during periods of high DOC. However, $\mathrm{pH}$ was low during periods of high DOC, and humic compounds become more hydrophobic and thus less labile to bacterial exoenzymes at low pH (Edling \& Tranvik, 1996), which could explain the lack of response of BP to higher DOC. Blackwater rivers are more acidic and have higher DOC concentrations and more degraded humic solutes (Leenheer, 1980; Ertel et al., 1986; Hedges et al., 1986) than clearwater rivers, which may have implications for DOC availability and may explain lower overall BP in blackwater compared with clearwater rivers. In addition, inputs of organic matter from riparian sources dominate in clearwater rivers, resulting in more labile DOC than in blackwater rivers, where groundwater inputs are the main sources of DOC (McClain, Richey \& Brandes, 1997).

Seasonal changes in BP and allochthonous inputs could explain the temporal variation in bacterial numbers. Comparison of bacterial doubling times to water residence times (Fig. 7) suggested that the number of bacteria generated from BP in the river can account for the observed variation in bacterial abundance, as suggested previously for the Autana River (Castillo, 2000). However, supplemental inputs of bacteria from the land may contribute to the observed increase in bacterial abundance during periods of high flow, when doubling time is higher and water residence time is lower.

By determining the connectivity of floodplain lakes with the river mainstem, seasonal variation in discharge influences the availability of algal carbon during periods of very low discharge. Higher chlorophyll $a$ (Fig. 3), and an earlier increase in BP, in blackwater compared with clearwater rivers during the 1998 dry season suggests that floodplain lakes could represent a source of algal carbon to the river mainstem. Floodplain lakes in the Autana River exhibited relatively high chlorophyll $a$ concentrations (3-6 $\mu \mathrm{g} \mathrm{L}^{-1}$ ) during the 1998 period of low water 

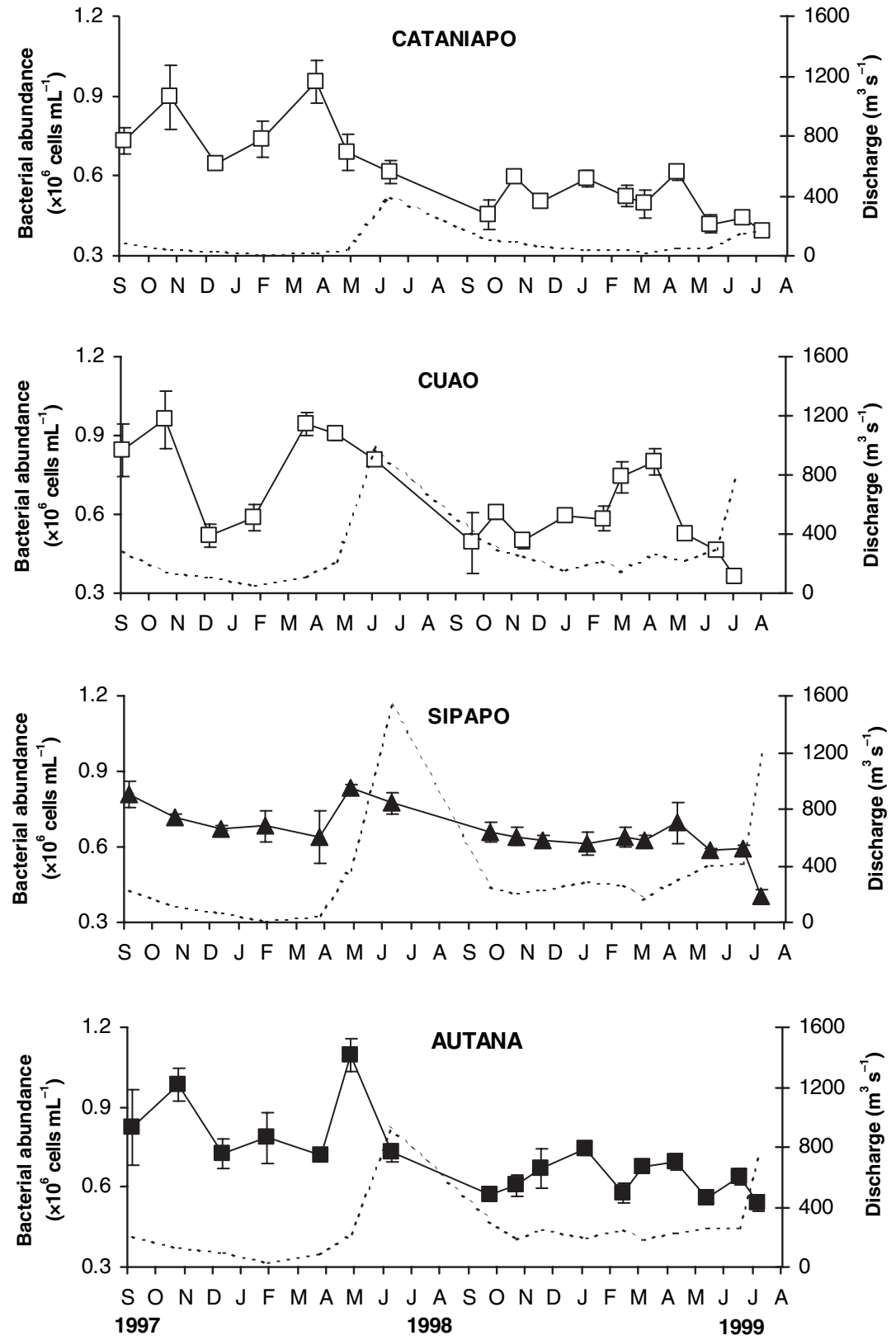

Fig. 6 Bacterial abundance in study rivers for the period September 1997 to July 1999. Error bars represent one standard deviation. Discharge values $(Q)$ are shown as dotted lines. Data for the Autana River for the period September 1997 to June 1998 were taken from Castillo (2000).
(Castillo, 2000). Although connection between the river and the lakes was limited, water flowed from the lakes into the river during low water, and this flow could have transported algal carbon from floodplain lakes to the river channel. Therefore, the presence of floodplain lakes could affect the amount of algal carbon in the rivers, which in turn could influence the temporal patterns in BP.

Interannual differences in the patterns of BP appear to be related to differences in the amount and timing of rainfall between years, providing further evidence of hydrologic influence. Low rainfall during the 1998 dry season, which was unusually dry because of a strong El Niño (ENSO, El Niño Southern Oscillation) phenomenon in the region (Bell et al., 1999), probably reduced inputs of allochthonous organic carbon and resulted in lower DOC concentrations at all river sites; however, low flows favoured higher chlorophyll $a$ concentrations and increased BP during low water. In blackwater rivers, very low discharge enhanced productivity in floodplain lakes and inputs of algal carbon into the river main stems. During 1999, which 
Fig. 7 Bacterial doubling times: water residence times ratios in the study rivers for the period September 1997 to July 1999. Values below the horizontal line indicate that bacterial doubling time are less than water residence time.

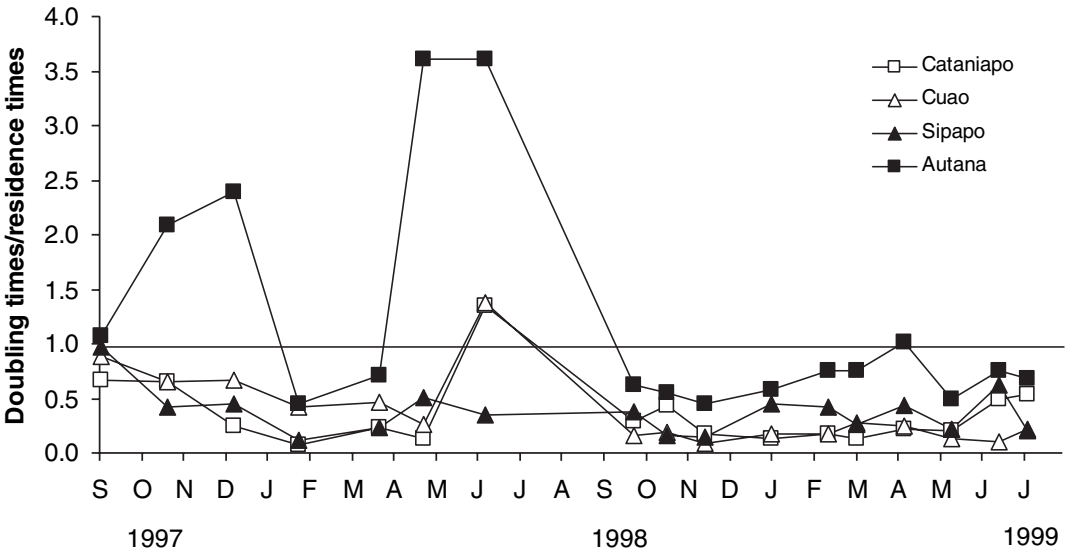

benthic bacteria on DOC cycling is not considered. In addition, differences in DOC concentration and in $\mathrm{BP}$ between blackwater and clearwater rivers imply that the impact of bacteria on DOC pools and cycling will differ between the two river types. On average, bacteria are expected to use $8.6 \%$ of the DOC pool in clearwater rivers versus $1.8 \%$ in blackwater rivers during the residence time of water in the rivers. These field estimates are close to the average values calculated from bioassay experiments for the Cataniapo $(15 \%)$ and the Autana $(0.9 \%)$ (Castillo et al., 2003). Because these calculations are for the entire pool of DOC, certain portions of the DOC pool, such as amino acids or other labile compounds, could be affected more strongly by bacterial processing.

\section{Bacterial production in tropical versus temperate systems}

Bacterial production measured in the water column of these four rivers of the Orinoco Basin was lower than recorded in other tropical and temperate rivers and lakes (Fig. 8), while bacterial abundances were within the range of values reported for other freshwater systems (Scavia \& Laird, 1987; Findlay et al., 1991; Morris \& Lewis, 1992; Benner et al., 1995). Estimates of

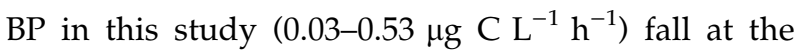
lower end of data from the Amazon system (0.19 to 2.6 $\mu \mathrm{g} \mathrm{C} \mathrm{L} \mathrm{L}^{-1} \mathrm{~h}^{-1}$ ); only the blackwater Rio Negro had BP similar to the rivers in this study (Benner et al., 1995). Among temperate-zone rivers, only the Ogeechee River and Black Creek, two blackwater systems in south-eastern U.S. (Edwards \& Meyer, 1986), had annual BP averages of the same order of magnitude as these Orinoco basin rivers. The high 


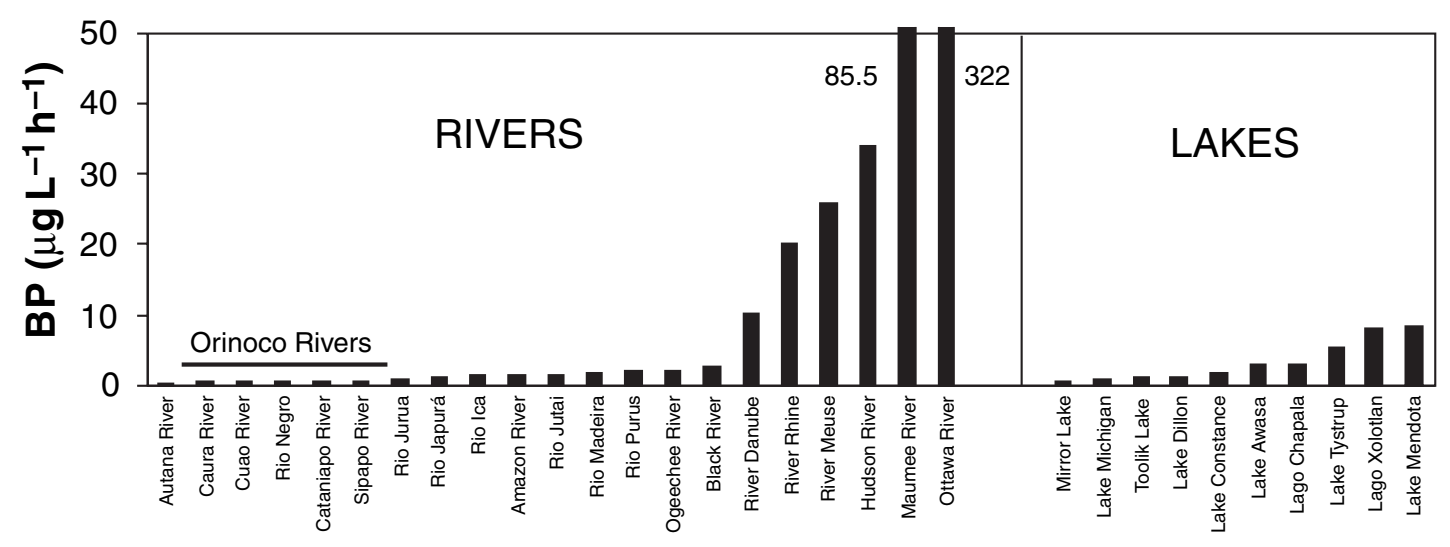

Fig. 8 Maximum bacterial production in several rivers and lakes. (Data from: Pedrós-Alió \& Brock, 1982; Riemann, 1983; Edwards \& Meyer, 1986; Scavia, Laird \& Fahnenstiel, 1986; Simon \& Tilzer, 1987; Servais, 1989; Gebre-Mariam \& Taylor, 1990; Morris \& Lewis, 1992; Admiraal et al., 1994; Benner et al., 1995; Berger et al., 1995; Lind, Chrzanowski \& Davalos-Lind, 1997; O’Brien et al., 1997; Sinsabaugh et al., 1997; Erikson et al., 1998).

content of humic substances in DOC, combined with low overall availability of phosphorus and low $\mathrm{pH}$ during times of high DOC, is likely to be responsible for the low BP found here.

Although seasonal changes in BP were substantial in the study rivers, the difference between seasonal maxima and minima of BP (measured as the maximum : minimum ratio) is much greater in temperate than in tropical rivers (Fig. 9) (Tukey $P<0.0001)$. In contrast, the range of values for seasonal variation in bacterial abundance overlap between tropical (maximum : minimum, 1.0-3.5) and temperate systems (1.9-57), although ratios are gen- erally higher in temperate systems. In the four study rivers, seasonal variation in $\mathrm{BP}$ (maximum : minimum, six to eight) was less marked than seasonal variation in discharge suggesting that, despite considerable seasonal and annual variation in discharge in tropical systems, the factors controlling BP throughout the year are more constant in tropical systems than in temperate rivers and lakes.

Differences between temperate and tropical systems in thermal regime and availability of substrate could underlie these differences in extent of seasonal variation in BP. Temperature is an important factor controlling bacterial metabolism (Edwards \& Meyer,

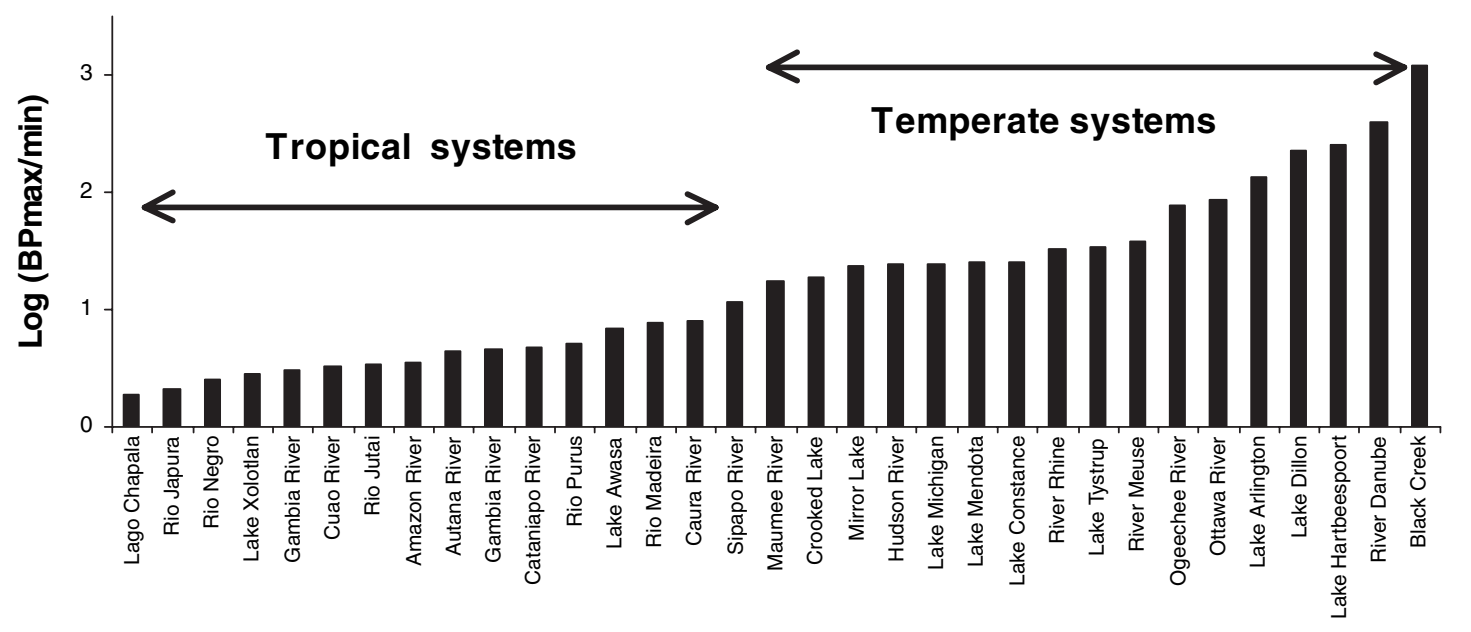

Fig. 9 Annual variation in bacterial production measured as the maximum : minimum ratio for several freshwater systems. A logarithmic transformation was applied to reduce the scale. (Data from: Pedrós-Alió \& Brock, 1982; Riemann, 1983; Edwards \& Meyer, 1986; Scavia et al., 1986; Simon \& Tilzer, 1987; Chrzanowski \& Hubbard, 1988; Healey et al., 1988; Servais, 1989; Gebre-Mariam \& Taylor, 1990; Robarts \& Wicks, 1990; Morris \& Lewis, 1992; Admiraal et al., 1994; Benner et al., 1995; Berger et al., 1995; LaybournParry, Bayliss \& Ellis-Evans, 1995; Ochs et al., 1995; Lind et al., 1997; Sinsabaugh et al., 1997; Erikson et al., 1998). 
1986; Coveney \& Wetzel, 1995; Ochs et al., 1995), and temperate systems experience a greater seasonal temperature range. When maximum : minimum ratios were calculated separately for warmer (May to September) and cooler months (October to April), overall variation tended to decline, but variation for temperate rivers during the summer was still higher than variation for tropical rivers (Tukey, $P<0.049$ ) (Fig. 10). This finding suggests that temperature is not the only factor driving differences in seasonal variation in BP between tropical and temperate systems and that fluctuations in other factors influencing BP, such as substrate and nutrient availability, are also greater in temperate than in tropical systems.

Temperate-zone rivers may experience greater substrate and inorganic nutrient availability than tropical rivers as a consequence of anthropogenic inputs, which may influence the magnitude and seasonal variation of BP (Admiraal et al., 1994; Sinsabaugh et al., 1997). Tropical rivers within the Amazon and Orinoco Basins are less influenced by human development than are most temperate-zone rivers. Seasonal variation in DOC, inorganic nutrients and chlorophyll a concentrations were relatively low in the Orinoco rivers (Table 2), despite greater variation in discharge, and so conditions for BP were relatively constant throughout the year. Although estimates of BP for undisturbed temperate rivers are not available, oligotrophic lakes such as Lake Michigan and Mirror Lake tended toward lower variation in $\mathrm{BP}$ during the warmer months than did non-oligotrophic lakes (Fig. 10), suggesting that substrate and inorganic nutrient availability could also be relatively constant in these low-productivity systems. Although data to compare means and ranges of BP between tropical and temperate systems are still too few for strong conclusions, the patterns shown in Figs 9 and 10 are probably the result of differences in seasonal variation in temperature, sources and availability of substrate to bacteria, and human disturbance that affects the supply of limiting substrates.

In summary, interannual and seasonal changes in discharge were accompanied by trends in chlorophyll, DOC, and phosphorus concentrations that in turn influenced variation in $\mathrm{BP}$, despite differences in water chemistry between blackwater and clearwater rivers. However, the presence of floodplain lakes in the blackwater rivers may interact with patterns of rainfall to affect the magnitude and timing of delivery of algal-derived DOC into blackwater rivers, especially under low flow conditions. Annual discharge exhibited distinct differences between the first and second years of study, probably because of the influence of the ENSO phenomena. Thus, increases in rainfall and fluctuations in discharge because of stronger or more frequent ENSO phenomena could affect the activity of heterotrophic bacteria by influencing the delivery of terrestrial carbon and floodplain-lake algae to rivers. Although this marked hydrologic seasonality

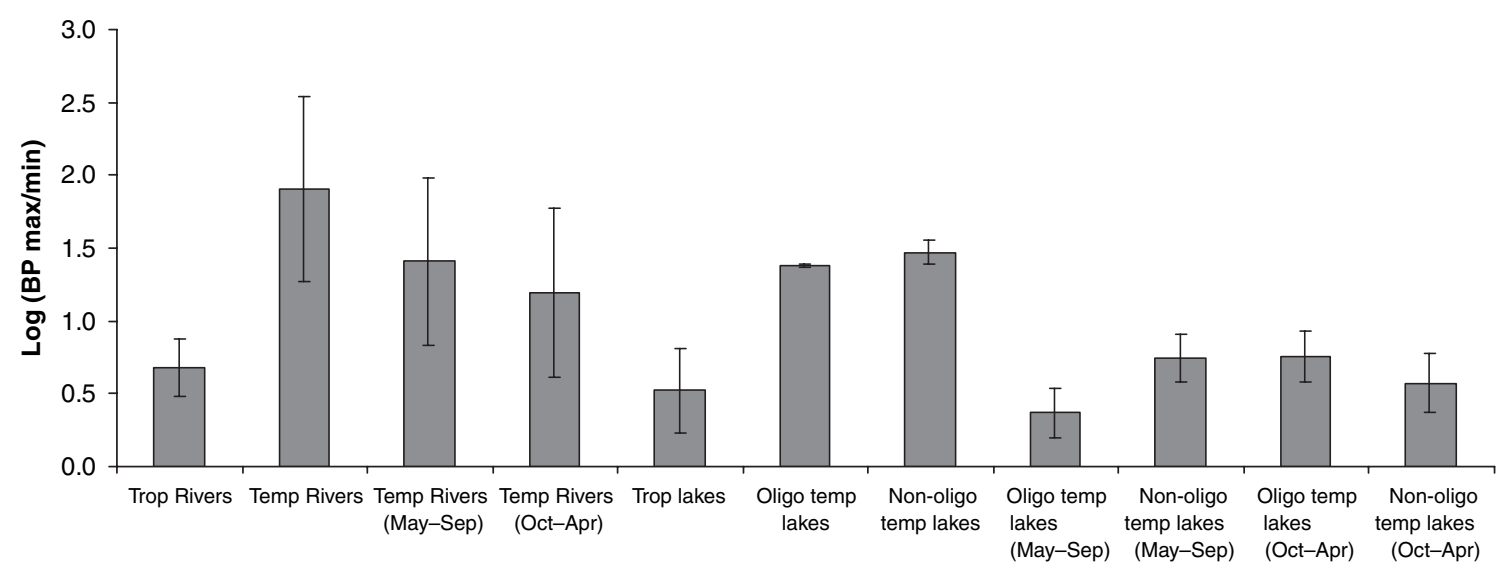

Fig. 10 Average annual and seasonal variation in bacterial production (maximum/minimum). For temperate systems, the ratio was calculated separately for the warmer months (May to September) and the cooler months (October to April). The ratio was also calculated separately for oligotrophic temperate lakes (Lake Michigan and Mirror lake) and for non-oligotrophic lakes (Lake Constance and Lake Tystrup). For data sources see Fig. 9. A logarithmic transformation was applied to reduce the scale. Error bars represent one standard deviation. 
was accompanied by variation in $\mathrm{BP}$, the variation was relatively low compared with most temperate rivers, suggesting that conditions promoting bacterial growth are relatively constant throughout the year in these undisturbed tropical lowland rivers.

\section{Acknowledgments}

We thank Gary Fowler for advice on the statistical analyses. We thank J. Papadakis, M. Melguero, S. Astiz, J. Alfonzo, S. Mendoza, J.V. Montoya, K. Riseng, M. Brahce, C. Wallace, and M. Costa for competent assistance in the field and the laboratory. We also appreciate the helpful comments of two anonymous reviewers. The Universidad Simòn Bolívar and the Estación Experimental Amazonas provided access to their laboratory facilities in Caracas and Puerto Ayacucho. This study was supported by the National Science Foundation grants DEB 9553064 (to G.W.K.) and DEB9801092 (to J.D.A., G.W.K., and M.M.C) and fellowships from the Graduate Women in Science and the University of Michigan Horace H. Rackham School of Graduate Studies (to M.M.C.)

\section{References}

A.P.H.A. (1995) Standard Methods for the Examination of Water and Wastewater, 17th edn. A.P.H.A., Washington D.C.

Admiraal W., Breebaart L., Tubbing G.M.J., Van Zanten B., De Ruijter Van Steveninck E.D \& Bijkerk R. (1994) Seasonal variation in composition and production of planktonic communities in the lower River Rhine. Freshwater Biology, 32, 519-531.

Bell R.T. (1993) Estimating production of heterotrophic bacterioplankton via incorporation of tritiated thymidine. In: Handbook of Methods in Aquatic Microbial Ecology (Eds P.F Kemp, B.F. Sherr, E.B. Sherr \& J.J. Cole), pp. 495-503. Lewis Publishers, Boca Raton.

Bell G.D., Halpert M.S., Ropelewski C.F., Kousky V.E., Douglas A.V., Schnell R.C. \& Gelman M.E. (1999) Climate assessment for 1998. Bulletin of the American Meteorological Society, 80, S1-S48.

Bell, G.D., Halpert M.S., Schnell C., Higgins R.W., Lawrimore J., Kousky V.E., Tinker R., Thiaw W., Chelliah M. \& Artusa A. (2000) Climate Assessment for 1999. Bulletin of the American Meteorological Society, 81, S3-S50.

Benner R., Opsahl S., Chin-Leo G., Richey J.E. \& Forsberg B.R. (1995) Bacterial carbon metabolism in the Amazon
River system. Limnology and Oceanography, 40, 12621270.

Berger B., Hoch B., Kavka G. \& Herndl G.J. (1995) Bacterial metabolism in the river Danube: parameters influencing bacterial production. Freshwater Biology, 34, 601-616.

Castillo M.M. (2000) Influence of hydrological seasonality on bacterioplankton in two neotropical floodplain lakes. Hydrobiologia, 437, 57-65.

Castillo M.M., Kling G.W. \& Allan J.D. (2003) Bottom-up controls on bacterial production in tropical lowland rivers. Limnology and Oceanography, 48, 1466-1475.

Chrzanowski T.H. \& Hubbard J.G. (1988) Primary and bacterial secondary production in a southwestern reservoir. Applied Environmental Microbiology, 54, 661669.

Coveney M.F. \& Wetzel R.G. (1995) Biomass, production, and specific growth rate of bacterioplankton and coupling to phytoplankton in an oligotrophic lake. Limnology and Oceanography, 40, 1187-1200.

Edling H. \& Tranvik L.R. (1996) Effects of $\mathrm{pH}$ on B-glucosidase activity and availability of DOC to bacteria in lakes. Archiv für Hydrobiologie/Advances in Limnology, 48, 123-132.

Edwards R.T. \& Meyer J.L. (1986) Production and turnover of planktonic bacteria in two southeastern blackwater rivers. Applied Environmental Microbiology, 52, 1317-1323.

Erikson R., Vammen K., Zelaya A. \& Bell R.T. (1998) Distribution and dynamics of bacterioplankton production in a polymictic tropical lake (lago Xolotlan, Nicaragua). Hydrobiologia, 382, 27-39.

Ertel J.R., Hedges J.I., Devol A.H., Richey J.E. \& Goes Ribero M.N. (1986) Dissolved humic substances of the Amazon River system. Limnology and Oceanography, 31, 739-775.

Felip M., Pace M.L. \& Cole J.J. (1996) Regulation of planktonic bacterial growth rates: the effects of temperature and resources. Microbial Ecology, 31, 15-28.

Findlay S., Pace M.L., Lints D., Cole, J.J., Caraco N.F. \& Peierls B. (1991) Weak coupling of bacterial and algal production in a heterotrophic ecosystem: the Hudson River estuary. Limnology and Oceanography, 36, 268278.

Findlay S., Pace M.L., Lints D. \& Howe K. (1992) Bacterial metabolism of organic carbon in the tidal freshwater Hudson Estuary. Marine Ecology Progress Series, 89, 147-153.

Gebre-Mariam Z. \& Taylor W.D. (1990) Heterotrophic bacterioplankton production and grazing mortality rates in an Ethiopian rift-valley lake (Awasa). Freshwater Biology, 22, 369-381. 
Healey M.J., Moll R.A. \& Diallo C.O. (1988) Abundance and distribution of bacterioplankton in the Gambia River, West Africa. Microbial Ecology, 16, 291-310.

Hedges J.I., Ertel J.R., Quay P.D., Grootes P.M., Richey J.E., Devol A.H., Farwell G.W., Schmidt F.W. \& Salati E. (1986) Organic carbon-14 in the Amazon river system. Science, 231, 1129-1131.

Hobbie J.E., Daley R.J. \& Jasper S. (1977) Use of nucleopore filters for counting bacteria by fluorescence microscopy. Applied Environmental Microbiology, 33, 1225-1228.

Huber, O. (1995) Vegetation. In: Flora of the Venezuelan Guayana, volume 1: Introduction (Eds P.E. Berry, B.K. Holst \& K. Yatskievych), pp. 97-160. Timber Press, Portland.

Kirchman D.L. (1990) Limitation of bacterial growth by dissolved organic matter in the subartic Pacific. Marine Ecology Progress Series, 62, 47-54.

Kirchman D.L. (1993) Leucine incorporation as a measure of biomass production by heterotrophic bacteria. In Handbook of Methods in Aquatic Microbial Ecology (Eds P.F Kemp, B.F. Sherr, E.B. Sherr \& J.J. Cole), pp. 509512. Lewis Publishers, Boca Raton.

Laybourn-Parry J., Bayliss P. \& Ellis-Evans J.C. (1995) The dynamics of heterotrophic nanoflagellates and bacterioplankton in a large ultra-oligotrophic Antarctic lake. Journal of Plankton Research, 17, 1835-1850.

Leenheer J.A. (1980) Origin and nature of humic substances in the waters of the Amazon river. Acta Amazonica, 10, 513-526.

Lewis W.M. Jr, Saunders J.F. III \& Dufford R. (1990) Suspended organisms and biological carbon flux along the Lower Orinoco river. In: The Orinoco River as an Ecosystem (Eds F.H. Weibezahn, H. Alvarez \& W.M. Lewis Jr), pp. 269-300. Galac, Caracas.

Lewis, W.M. Jr, Hamilton, S.K. \& Saunders, J.F. III (1995) Rivers of Northern South America. In: River and Stream Ecosystems (Eds C.E. Cushing, K.W. Cummins \& G.W. Minshall), pp. 219-256. Elsevier, Amsterdam.

Lind O.T., Chrzanowski T.H. \& Davalos-Lind L. (1997) Clay turbidity and the relative production of bacterioplankton and phytoplankton. Hydrobiologia, 353, $1-18$.

McClain M.E., Richey J.E. \& Brandes J.A. (1997) Dissolved organic matter and terrestrial-lotic linkages in the central Amazon Basin of Brazil. Global Biogechemical Cycles, 11, 295-311.

Meyer J.L. (1994) The microbial loop in flowing waters. Microbial Ecology, 28, 195-199.

Morris D.P. \& Lewis, W.M. Jr. (1992) Nutrient limitation of bacterioplankton growth in Lake Dillon, Colorado. Limnology and Oceanography, 6, 1179-1192.
Nusch E.A. (1980) Comparison of different methods for chlorophyll and phaeopigment determination. Archiv für Hydrobiologie/Advances in Limnology, 14, 14-36.

O'Brien W.J., Bahr M., Hershey A.E. et al. (1997) The limnology of Toolik lake. In: Freshwaters of Alaska: Ecological Syntheses (Eds M.A. Milner \& M.W. Oswood), pp. 61-106. Springer-Verlag, New York.

Ochs C.A., Cole J.J. \& Likens G.E. (1995) Population dynamics of bacterioplankton in an oligotrophic lake. Journal of Plankton Research, 17, 365-391.

Pace M.L. \& Cole J.J. (1994) Comparative and experimental approaches to Top-Down and Bottom-Up regulation of bacteria. Microbial Ecology, 28, 181-193.

Pedrós-Alió C. \& Brock T.D. (1982) Assessing biomass and production of bacteria in eutrophic lake Mendota, Wisconsin. Applied Environmental Microbiology, 44, 203218.

Richey J.E., Hedges J.I., Devol A.H. \& Quay P.D. (1990) Biogeochemistry of carbon in the Amazon River. Limnology and Oceanography, 35, 352-371.

Riemann B. (1983) Biomass and production of phyto- and bacterio-plankton in eutrophic Lake Tystrup, Denmark. Freshwater Biology, 13, 389-398.

Robarts R.D. \& Wicks R.J. (1990) Heterotrophic bacterial production and its dependence on autotrophic production in a hypertrophic African Reservoir. Canadian Journal of Fisheries and Aquatic Sciences, 47, 1027-1037.

Scavia D. \& Laird G.A. (1987) Bacterioplankton in Lake Michigan: dynamics, controls, and significance to carbon flux. Limnology and Oceanography, 32, 10171033.

Scavia D., Laird G.A. \& Fahnenstiel G.L. (1986) Production of planktonic bacteria in Lake Michigan. Limnology and Oceanography, 31, 612-626.

Servais P. (1989) Bacterioplanktonic biomass and production in the river Meuse (Belgium). Hydrobiologia, 174, 99-110.

Simon M. \& Azam F. (1989) Protein content and protein synthesis rates of planktonic marine bacteria. Marine Ecology Progress Series, 51, 201-213.

Simon M. \& Tilzer M.M. (1987) Bacterial response to seasonal changes in primary production and phytoplankton biomass in Lake Constance. Journal of Plankton Research, 9, 535-552.

Sinsabaugh R.L., Findlay S., Franchini P. \& Fisher, D. (1997) Enzymatic analysis of riverine bacterioplankton production. Limnology and Oceanography, 42, 29-38.

Sioli H. (1984) The Amazon and its main affluents: hydrography, morphology of the river courses and river types. In: The Amazon: Limnology and Landscape Ecology of a Mighty Tropical River and Its Basin (Ed. H. Sioli), pp. 127-165. Dr. W. Junk Publishers, Dordrecht. 
1414 M.M. Castillo et al.

Turley C.M. (1993) Direct estimates of bacterial numbers in seawater samples without incurring cell loss due to sample storage. In: Handbook of Methods in Aquatic Microbial Ecology (Eds P.F Kemp, B.F. Sherr, E.B. Sherr \& J.J. Cole), pp. 143-147. Lewis Publishers, Boca Raton.

Weibezahn F.H. (1990) Hidroquímica y sólidos suspendidos en el alto y medio Orinoco. In: The Orinoco River as an Ecosystem (Eds F.H. Weibezahn, H. Alvarez \& W.M. Jr. Lewis), pp. 150-210. Galac, Caracas.

Wetzel R.G. (1995) Death, detritus, and energy flow in aquatic ecosystems. Freshwater Biology, 33, 83-89.

Wetzel R.G. \& Likens G.E. (1991) Limnological Analyses, 2nd edn. Springer-Verlag, New York.

(Manuscript accepted 4 August 2004) 